\title{
PENGARUH PROFITABILITAS DAN LEVERAGE TERHADAP AGRESIVITAS PAJAK
}

\author{
Pajar Sidik ${ }^{1}$ \\ Suhono $^{2}$ \\ Universitas Singaperbangsa Karawang, Jawa Barat, Indonesia ${ }^{1,2}$ \\ Email: Pajar.sidik16214@ student.unsika.ac.id ${ }^{1}$ suhono@fe.unsika.ac.id ${ }^{2}$
}

\begin{abstract}
This study aims to determine the effect of profitability on tax aggressiveness, the effect of leverage on tax aggressiveness, and the effect of profitability and leverage on tax aggressiveness. The government can also use tax revenue to build and improve public infrastructure so as to improve people's welfare. Therefore, the government always tries to increase the tax target from year to year through various policies. Tax revenue plays an important role in supporting government operations, because the size of the tax revenue will determine the amount of the APBN. 100 samples were taken from 2015 to 2019 with annual data on ROA, Leverage and Tax Aggressiveness. The statistical method used in this research is multiple regression analysis, classical assumption test, descriptive statistical analysis, determination analysis and hypothesis testing. From the results of this study it is known that profitability has a negative effect on tax aggressiveness. Leverage has no effect on tax aggressiveness. Profitability and Leverage have an effect on Tax Aggressiveness.
\end{abstract}

Keywords: Profitability; Leverage; Tax Aggressiveness.

\begin{abstract}
ABSTRAK
Penelitian ini bertujuan untuk mengetahui pengaruh profitabilitas terhadap agresivitas pajak, pengaruh leverage terhadap agresivitas pajak, serta pengaruh profitabilitas dan leverage terhadap agresivitas pajak. Pemerintah juga dapat menggunakan penerimaan pajak untuk membangun dan meningkatkan infrastruktur publik sehingga dapat meningkatkan kesejahteraan rakyat. Oleh karena itu, pemerintah selalu berupaya meningkatkan target perpajakan dari tahun ke tahun melalui berbagai kebijakan. Penerimaan perpajakan berperan penting dalam menunjang operasional pemerintah, karena besar kecilnya penerimaan pajak akan menentukan besaran APBN. Sampel yang diambil 100 dari tahun 2015 sampai 2019 dengan data tahunan ROA, Leverage dan Agresivitas Pajak. Metode statistik yang diambil dalam penelitian ini adalah analisis regresi berganda, uji asumsi klasik, analisis statistik deskriptif, analisis determinasi dan pengujian hipotesis. Dari hasil penelitian ini diketahui bahwa Profitabilitas berpengaruh negatif terhadap Agresivitas Pajak. Leverage tidak berpengaruh terhadap Agresivitas Pajak. Profitabilitas dan Leverage berpengaruh terhadap Agresivitas Pajak.
\end{abstract}

Kata kunci: Profitabilitas; Leverage; Agresivitas Pajak. 


\section{PENDAHULUAN}

Menurut pasal 1 ayat (1) undang-undang nomor 16 tahun 2009, pajak merupakan kontribusi wajib kepada negara yang terutang oleh orang pribadi atau badan yang bersifat memaksa berdasarkan undang-undang dengan tidak mendapat imbalan secara langsung dan digunakan sebesar-besarnya bagi kemakmuran rakyat (Undang-Undang No.16 Tahun 2009 Tentang Ketentuan Umum dan Tata Cara Perpajakan, 2009). Sektor perpajakan merupakan salah satu sumber pendapatan negara yang paling penting, sehingga perlu dilakukan pembenahan dan pembinaan pengawasan serta pemanfaatannya sebagai sumber pendapatan nasional. Sebagaimana dinyatakan dalam APBN, pajak merupakan sumber penerimaan negara yang paling besar. Pajak dapat digunakan sebagai sarana atau alat bagi pemerintah untuk mewujudkan pemerintahan yang baik dan berkelanjutan.

Pemerintah juga dapat menggunakan penerimaan pajak untuk membangun dan meningkatkan infrastruktur publik sehingga dapat meningkatkan kesejahteraan rakyat. Oleh karena itu, pemerintah selalu berupaya meningkatkan target perpajakan dari tahun ke tahun melalui berbagai kebijakan. Penerimaan perpajakan berperan penting dalam menunjang operasional pemerintah, karena besar kecilnya penerimaan pajak akan menentukan besaran APBN.

Kontribusi penerimaan pajak terhadap pendapatan negara selalu berada di atas $74 \%$ setiap tahunnya. Hal ini mencerminkan bahwa porsi pendapatan negara yang berasal dari penerimaan pajak sangat besar sekali. Pembangunan dan peningkatan kesejahteraan masyarakat tidak terlepas dari peran pajak dalam 
APBN. Dapat dikatakan pajak menjadi tulang punggung roda pemerintahan negara untuk meningkatkan taraf hidup masyarakat.

Tabel 1.

Kontribusi Penerimaan Pajak Terhadap Pendapatan Negara (Dalam Triliun Rupiah)

\begin{tabular}{cccc}
\hline Tahun & Pendapatan Negara & Penerimaan Pajak & Persentase \\
\hline 2014 & 1.545 & 1.147 & $74 \%$ \\
2015 & 1.496 & 1.240 & $83 \%$ \\
2016 & 1.547 & 1.285 & $83 \%$ \\
2017 & 1.733 & 1.473 & $85 \%$ \\
2018 & 1.893 & 1.618 & $85 \%$ \\
\hline
\end{tabular}

Sumber : BPS, 2015

Fenomena yang sering terjadi adalah terdapat perbedaan kepentingan antara pemerintah dengan perusahaan selaku wajib pajak. Pemerintah berusaha untuk memperoleh penerimaan pajak yang sebesar besarnya karena segala kegiatan pemerintahan sebagian besar ditunjang dari penerimaan pajak. Sedangkan sebaliknya perusahaan berusaha untuk membayar pajaknya seminimal mungkin untuk dapat memaksimalkan laba bersih tahun berjalan. Hal tersebut membuat banyak perusahaan untuk melakukan manajemen pajak semaksimal mungkin.

Berikut adalah data penerimaan pajak tahun 2010-2019, kenyataannya penerimaan pajak di Indonesia masih belum mampu tercapai dengan maksimal. Realisasi penerimaan pajak setiap tahunnya masih dibawah target yang telah ditetapkan pemerintah. Belum mampunya pemerintah dalam mencapai target penerimaan pajak setiap tahunnya menimbulkan pertanyaan apakah perusahaanperusahaan melakukan manajemen pajak agresif, ataukah memang sebenarnya pemerintah belum mampu melakukan pemungutan secara maksimal. 
Tabel 2.

Target dan Realisasi Penerimaan Pajak Periode 2010-2019 (Dalam Triliun Rupiah)

\begin{tabular}{cccc}
\hline Tahun & Target & Realisasi & Capaian \\
\hline 2010 & 661,50 & 569,02 & $86,02 \%$ \\
2011 & 763,67 & 742,72 & $97,26 \%$ \\
2012 & 885,03 & 835,83 & $94,44 \%$ \\
2013 & 995,20 & 921,40 & $92,58 \%$ \\
2014 & $1.072,38$ & 985,13 & $91,86 \%$ \\
2015 & $1.294,25$ & $1.060,86$ & $81,97 \%$ \\
2016 & $1.355,20$ & $1.105,97$ & $81,61 \%$ \\
2017 & $1.283,57$ & $1.151,13$ & $89,68 \%$ \\
2018 & $1.424,00$ & $1.315,00$ & $92,35 \%$ \\
2019 & $1.577,56$ & $1.332,10$ & $84,44 \%$ \\
\hline
\end{tabular}

Sumber : data diolah, 2019

Target dan realisasi penerimaan pajak selalu mengalami kenaikan setiap tahunnya. Kecuali tahun 2017 target penerimaan pajak mengalami penurunan, hal ini karena target tahun 2015 dan 2016 ditetapkan terlalu tinggi sehingga realisasi penerimaan pajak jauh dibawah target. Selain itu capaian penerimaan pajak dalam 10 tahun terakhir tidak pernah mencapai target yang ditetapkan. Tidak terpenuhinya target penerimaan pajak dapat diduga karena adanya tindakan agresivitas pajak yang dilakukan perusahaan.

Agresivitas pajak terjadi karena masih rendahnya tingkat kesadaran wajib pajak dalam membayar kewajiban pajaknya. Berdasarkan informasi yang dikeluarkan oleh Kementerian Keuangan Republik Indonesia dalam APBN 2018, Tax Ratio Indonesia tahun 2013 sebesar 14,3\%, tahun 2014 sebesar 13,7\%, tahun 2015 sebesar 11,6\%, tahun 2016 sebesar 10,6\%, dan tahun 2017 sebesar 11,5\%. Hal ini menggambarkan bahwa Tax Ratio Indonesia terus mengalami penurunan dari tahun 2013-2016 sedangkan baru mengalami peningkatan pada tahun 2017. 
Walaupun mengalami peningkatan, Tax Ratio Indonesia masih berada pada persentase $11,5 \%$ yang artinya masih berada dibawah standar negara-negara Association of South East Asia Nations (ASEAN) (Kementrian Keuangan, 2018).

Selain terendah di Asia Pasifik, rasio pajak Indonesia berada di bawah rata-rata Organisasi untuk Kerjasama Ekonomi dan Pembangunan atau OECD sebesar $34,2 \%$, bahkan juga di bawah LAC dan Afrika yang rata-ratanya $22 \%$ dan 18,2\%. Menurut laporan Organisation for Economic Co-operation and Development (OECD), penyebab rendahnya tax ratio Indonesia salah satunya adalah penghindaran pajak serta basis pemajakan yang rendah. Fenomena rendahnya tingkat rasio pajak Indonesia dapat mengindikasikan adanya tindakan manajemen pajak agresif yang telah dilakukan oleh para wajib pajak.

Forum Indonesia Untuk Transparansi Anggaran (FITRA) menuturkan bahwa setiap tahun diduga ada Rp 110 triliun angka penghindaran pajak. Sebanyak 80 persen dilakukan oleh badan usaha dan 20 persen sisanya dilakukan wajib pajak perorangan. Sementara menurut laporan Global Financial Integrity dalam kurun waktu 2004 - 2013, dana illegal yang keluar dari Indonesia mencapai Rp 2.100 triliun (Suara.com, 2017).

Menurut Frank et.al dalam (Kamila \& Martani, 2014) agresivitas pajak merupakan tindakan yang ditujukan untuk menurunkan laba kena pajak melalui perencanaan pajak, baik menggunakan cara yang tergolong atau tidak tergolong tax evasion. Walaupun cara-cara yang dilakukan tidak melanggar aturan, namun semakin banyak celah yang dimanfaatkan maka perusahaan tersebut dianggap semakin agresif terhadap pajak. Tindakan agresivitas pajak dapat dilakukan 
karena masih lemahnya Undang-Undang perpajakan termasuk sumber daya manusianya. Sehingga hal tersebut dapat menjadi peluang bagi perusahaan untuk mengurangi jumlah pajak yang harus dibayar.

Salah satu faktor yang digunakan untuk mengukur tingkat agresivitas pajak adalah dengan menggunakan profitabilitas. Profitabilitas adalah kemampuan perusahaan dalam menghasilkan laba dari aktivitas bisnisnya (Hanafi, 2012). Return on Assets (ROA) merupakan salah satu rasio yang mencerminkan profitabilitas suatu perusahaan. Semakin tinggi tingkat profitabiitas maka semakin tinggi pula laba yang dihasilkan perusahaan. Besarnya pajak yang dibayarkan tergantung dari laba yang dihasilkan, karena laba merupakan dasar pengenaan pajak perusahaan.

Ukuran lain yang dapat digunakan untuk mengukur tingkat agresivitas pajak adalah leverage. Leverage merupakan rasio yang mencerminkan besarnya modal dari pihak ketiga yang digunakan perusahaan untuk melakukan aktivitas operasinya (Kasmir, 2014). Sumber dana pinjaman yang tinggi akan membuat beban bunga yang ditanggung perusahaan menajadi tinggi. Beban bunga akan mengurangi laba perusahaan, sehingga dengan berkurangnya jumlah laba maka akan mengurangi beban pajak yang ditanggung perusahaan. Perusahaan dapat menggunakan tingkat leverage sebagai alat untuk mengurangi beban pajak.

Penelitian yang dilakukan oleh (Luke \& Zulaikha, 2016) menunjukan bahwa Profitabilitas berpengaruh negatif pada agresivitas pajak, hal ini mencerminkan Profitabilitas berpengaruh positif terhadap tindakan agresivitas pajak perusahaan. Penelitian ini sejalan dengan penelitian yang dilakukan 
(Darmawan \& Sukartha, 2014) yang menyebutkan bahwa profitabilitas berpengaruh positif terhadap agresivitas pajak. Hal tersebut menunjukan bahwa perusahaan yang memiliki tingkat Profitabilitas tinggi cenderung tidak agresif dalam penghindaran pajak. Hal ini berbeda dengan penelitian yang dilakukan oleh (Yuliana \& Wahyudi, 2018) yang menunjukan bahwa profitabilitas berpengaruh negatif terhadap agresivitas pajak. Penelitian (Maharani \& Suardana, 2014) juga menunjukan bahwa profitabilitas berpengaruh negatif terhadap agresivitas pajak.

Menelitian mengenai tingkat leverage terhadap agresivitas pajak telah banyak dilakukan oleh beberapa peneliti. Penelitian yang dilakukan oleh (Yeye et al., 2018) menunjukan hasil bahwa leverage berpengaruh signifikan positif terhadap agresivitas pajak. Penelitian (Suyanto \& Supramono, 2012) juga menunjukan hubungan yang positif antara leverage dan agresivitas pajak. Hal ini dikarenakan dengan tingkat leverage yang besar, perusahaan akan memanfaatkan beban bunga untuk mengurangi laba kena pajak yang akan berdampak pada penurunan beban pajak.

Akan tetapi hal serupa tidak ditunjukan oleh penelitian dari (Susanto et al., 2018) yang memberikan hasil bahwa leverage tidak berpengaruh signifikan terhadap agresivitas pajak. Penelitian (Yuliana \& Wahyudi, 2018) juga menunjukan bahwa leverage berpengaruh negatif dan tidak signifikan terhadap agresivitas pajak. Dalam penelitian ini disebutkan bahwa perusahaan yang memiliki tingkat hutang yang tinggi akan diawasi oleh pihak pemberi pinjaman, sehingga perusahaan cenderung lebih patuh akan kesadaran kewajiban perpajakannya. 
Berdasarkan fenomena di atas penulis tertarik untuk melakukan penelitian lebih lanjut mengenai pengaruh profitabilitas dan leverage terhadap agresivitas pajak. Maka penulis kembali melakukan penelitian dengan judul "Pengaruh Profitabilitas dan Leverage Terhadap Agresivitas Pajak (studi kasus pada perusahaan manufaktur subsektor konsumsi yang terdaftar di Bursa Efek Indonesia periode 2015-2019)"'.

\section{METODE PENELITIAN}

Metode penelitian yang digunakan dalam penelitian ini yaitu analisis inferensia. Penelitian dilakukan pada perusahaan manufaktur sub sektor konsumsi yang terdaftar di Bursa Efek Indonesia periode 2015-2019. Metode pengumpulan data menggunakan metode dokumentasi dan studi pustaka. Jenis data yang digunakan merupakan data sekunder laporan keuangan tahunan periode 20152019 yang diperoleh dari website Bursa Efek Indonesia. Populasi pada penelitian ini adalah perusahaan manufaktur sub sektor konsumsi yang terdaftar di Bursa Efek Indonesia periode 2015-2019. Teknik pengambilan sambel menggunakan purposive sampling. Purposive sampling merupakan teknik pengambilan sampel dengan menggunakan pertimbangan tertentu atas dasar kepentingan dan tujuan penelitian (Sugiyono, 2012).

Berdasarkan pengertian tersebut maka peneliti menentukan kriteria yang akan digunakan adalah sebagai berikut: Perusahaan manufaktur subsektor konsumsi yang terdaftar di BEI; Perusahaan manufaktur subsektor konsumsi yang terdaftar di BEI dan menyediakan laporan keuangan selama periode penelitian 
2015-2019; Perusahaan manufakur subsektor konsumsi yang tidak mengalami kerugian selama periode penelitian 2015-2019 secara berturut-turut.

Sampel yang diperoleh berjumlah 20 perusahaan selama 5 tahun sehingga diperoleh sebanyak 100 data pengamatan. Adapun dalam pengumpulan data terdapat beberapa data yang menghasilkan pengujian statistik tidak dapat digunakan sebagai dasar pengambilan keputusan. Maka dari itu dilakukan outlier dan menghasilkan sebanyak 14 data pengamatan harus dikeluarkan dari pengujian.

Metode analisis data dalam penelitian ini menggunakan analisis regresi linear berganda, uji koefisien determinasi, dan uji hipotesis. Data diolah menggunakan software SPSS 25. Adapun persamaan dalam penellitia ini sebagai berikut:

$$
\mathrm{Y}=\alpha+\beta_{1} \cdot \mathrm{X}_{1}+\beta_{2} \cdot \mathrm{X}_{2}+\mathrm{e}
$$

Notasi :

$$
\begin{aligned}
\mathrm{Y} & =\text { Agresivitas Pajak } \\
\alpha & =\text { Konstanta } \\
\beta & =\text { Koefisien regresi } \\
\mathrm{X}_{1} & =\text { Profitabilitas } \\
\mathrm{X}_{2} & =\text { Leverage } \\
\mathrm{e} & =\text { Error term }
\end{aligned}
$$

\section{HASIL DAN PEMBAHASAN}

Analisis deskriptif yang digunakan dalam penelitian ini meliputi nilai mean, standar deviasi, maksimum dan minimum. Mean digunakan untuk mengetahui rata-rata data yang bersangkutan. Standar deviasi digunakan untuk mengetahui seberapa besar data yang bersangkutan bervariasi dan rata-rata. 
Maksimum digunakan untuk mengetahui jumlah terbesar data yang bersangkutan. Minimum digunakan untuk mengetahui jumlah terkecil data yang bersangkutan (Ghozali, 2018).

Tabel 3.

Hasil Analisis Statistik Deskriptif

\begin{tabular}{lccccc}
\hline \multicolumn{1}{c}{ Variabel } & N & Minimum & Maximum & Mean & $\begin{array}{c}\text { Std. } \\
\text { Deviation }\end{array}$ \\
\hline ROA & 86 &, 09 & 30,02 & 10,5187 & 7,39166 \\
LEVERAGE & 86 & 14,63 & 76,99 & 35,6522 & 15,57617 \\
ETR & 86 &, 21 &, 32 &, 2555 &, 02162 \\
\hline Sumber: Data diolah peneliti, 2020 & & & &
\end{tabular}

ROA mempunyai nilai mean sebesar 10,5187 , lebih besar dari nilai standar deviasi sebesar 7,39166 (mean 10,5187 > standar deviasi 7,3916), hal ini berarti sebaran data variabel ROA sudah merata dan cenderung homogen. Kemudian nilai minimum sebesar 0,09 persen ada pada Kimia Farma, Tbk tahun 2019 dan nilai maksimum sebesar 30,02 persen ada pada H.M Sampoerna, Tbk tahun 2016.

Leverage mempunyai nilai mean sebesar 35,6522, lebih besar dari nilai standar deviasi sebesar 15,57617 (mean 35,6522 > standar deviasi 15,57617), hal ini berarti sebaran data variabel leverage sudah merata dan cenderung homogen. Kemudian nilai minimum sebesar 14,63 persen ada pada Delta Djakarta, Tbk tahun 2017 dan nilai maksimum sebesar 76,99 persen ada pada Kino Indonesia, Tbk tahun 2015.

ETR mempunyai nilai mean sebesar 0,2555 , lebih besar dari nilai standar deviasi sebesar 0,02162 (mean 0,2555 > standar deviasi 0,02162), hal ini berarti sebaran data variabel ETR sudah merata dan cenderung homogen. 
Kemudian nilai minimum sebesar 0,21 persen ada pada Sekar Laut, Tbk tahun 2019 dan nilai maksimum sebesar 0,32 persen ada pada perusahaan Nippon Indosari Corporindo, Tbk tahun 2019, Indofood CBP Sukses Makmur, Tbk tahun 2017 dan Pyridam Farma, Tbk tahun 2015.

Uji normalitas adalah pengujian yang dilakukan untuk melihat apakah data yang akan diolah berdistribusi normal atau tidak (Ghozali, 2018). Model regresi yang baik adalah model regresi yang memiliki nilai residual yang mengikuti distribusi normal. Dasar pengambilan keputusan adalah jika signifikan $>0,05$, maka data memenuhi asumsi normalitas dan sebaliknya jika signifikan < 0,05, maka data tidak memenuhi asumsi normalitas. Dari hasil pengujian menunjukan nilai Sig. sebesar 0,200, lebih besar dibandingkan dengan 0,05. Hal ini menunjukan data berdistribusi normal.

Tabel 4.

Hasil Uji Normalitas

\begin{tabular}{lrc}
\hline & Unstandardized Residual & \multicolumn{1}{c}{ Keterangan } \\
\hline $\mathrm{N}$ & 86 & Data Berdistribusi Normal \\
Asymp. Sig. (2-tailed) &, $200^{\mathrm{c}, \mathrm{d}}$ & \\
\hline Sumber : Data diolah peneliti 2020 & & \\
\hline
\end{tabular}

Sumber : Data diolah peneliti, 2020

Uji multikolinearitas bertujuan untuk menguji apakah model regresi ditemukan adanya korelasi antar variabel independent (Ghozali, 2018). Model regresi yang baik seharusnya tidak terjadi korelasi di antara variabel independen. Jika VIF yang dihasilkan antara $<10$ maka tidak terjadi multikolinearitas. Dari pengujian diperoleh nilai VIF untuk variabel ROA dan leverage yaitu sebesar 1,264. Hal ini berarti nilai VIF lebih kecil dari 10,00. Sehingga dapat disimpulkan bahwa model regresi tidak terjadi atau bebas dari multikolinearitas. 
Tabel 5.

Uji Multikolinearitas

\begin{tabular}{lccc}
\hline \multirow{2}{*}{ Variabel } & \multicolumn{2}{c}{ Collinearity Statistic } & \multirow{2}{*}{ Keterangan } \\
\cline { 2 - 3 } & Tolerance & VIF & \\
\hline (Constant) & & & \\
ROA &, 791 & 1,264 & Tidak Terjadi Multikolinearitas \\
LEVERAGE &, 791 & 1,264 & Tidak Terjadi Multikolinearitas \\
\hline
\end{tabular}

Sumber : Data diolah peneliti, 2020

Uji heteroskedastisitas bertujuan menguji apakah dalam model regresi terjadi ketidaksamaan varians dari residual satu pengamatan ke pengamatan yang lain (Ghozali, 2018). Deteksi ada tidaknya heteroskedastisitas dapat dilakukan dengan melihat ada tidaknya pola pada grafik scatterplot. Pada gambar scatterplot terlihat bahwa titik-titik menyebar secara acak dan tidak membentuk pola tertentu yang jelas, serta menyebar baik diatas dan dibawah angka 0 pada sumbu Y. Hal ini berarti tidak terjadi heteroskedastisitas pada model regresi ini, sehingga regresi layak dipakai.

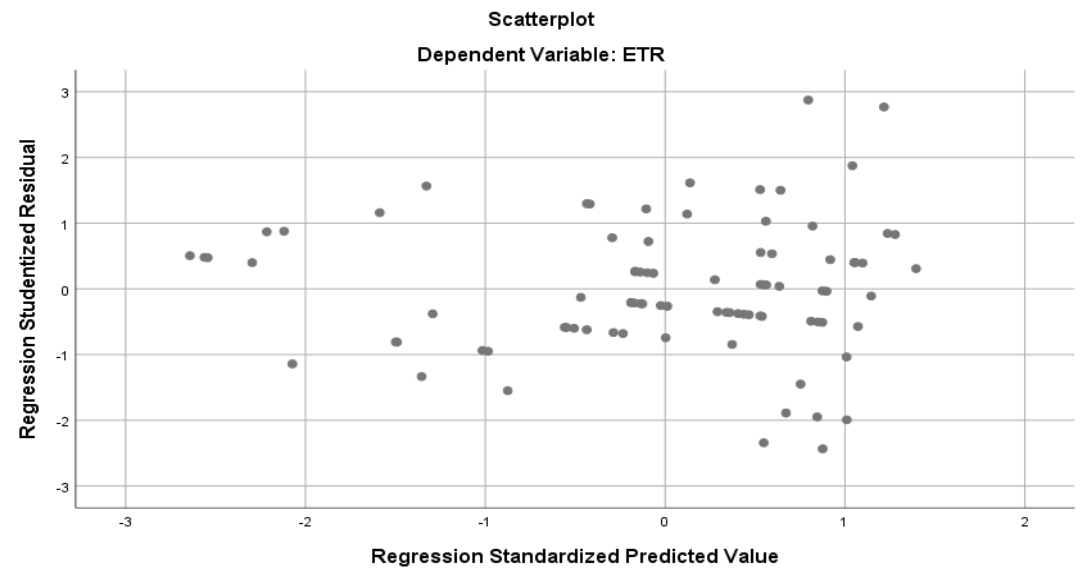

Sumber: Output SPSS 25, 2020

Gambar 1.

Hasil Uji Heteroskedastisitas 
Uji autokorelasi dalam suatu model bertujuan untuk mengetahui ada atau tidaknya korelasi antara variabel pengganggu pada periode tertentu dengan variabel sebelumnya (Ghozali, 2018). Model yang baik harus bebas dari autokorelasi. Pendekatan yang digunakan untuk menguji ada tidaknya autokorelasi uji Durbin-Watson (DW test). Dari hasil pengujian diperoleh nilai Durbin-Watson Sebesar 2,270. Nilai dU pada tabel Durbin-Watson dengan k=2 dan $\mathrm{N}=86$ berada di nilai 1,6942 . Karena nilai Durbin Watson berada diantara interval dU $(1,6942)<\mathrm{d}(2,270)<4-\mathrm{dU}(2,305)$ dapat disimpulkan bahwa model regresi ini bebas dari autokorelasi.

Tabel 6.

\section{Hasil Uji Autokorelasi}

\begin{tabular}{ccccc}
\hline Model & R & $\begin{array}{c}\text { R } \\
\text { Square }\end{array}$ & $\begin{array}{c}\text { Durbin- } \\
\text { Watson }\end{array}$ & Keterangan \\
\hline 1 & $273^{\mathrm{a}}$ & 0,074 & 2,270 & Tidak Terjadi Autokorelasi \\
\hline
\end{tabular}

Sumber: Data diolah peneliti, 2020

Analisis regresi linier berganda bertujuan untuk memprediksi besar variabel terikat dengan menggunakan variabel bebas yang telah diketahui besarnya (Ghozali, 2018). Regresi linier berganda digunakan untuk mengetahui pengaruh Profitabilitas dan Leverage sebagai variabel bebas terhadap Agresivitas Pajak sebagai variabel terikat.

Diperoleh hasil persamaan analisis regresi linear berganda sebagai berikut:

Agresivitas Pajak (Y) = 0,266 - 0,001 ROA -5,179 LEVERAGE

Berdasarkan persamaan regresi tersebut dapat diketahui bahwa : Nilai konstanta ( $\alpha$ ) sebesar 0,266, berarti jika variabel independen yaitu ROA dan leverage 
bernilai 0 atau konstan maka agresivitas pajak sebesar 0,266.

Tabel 7.

Hasil Uji Regresi Linear Berganda

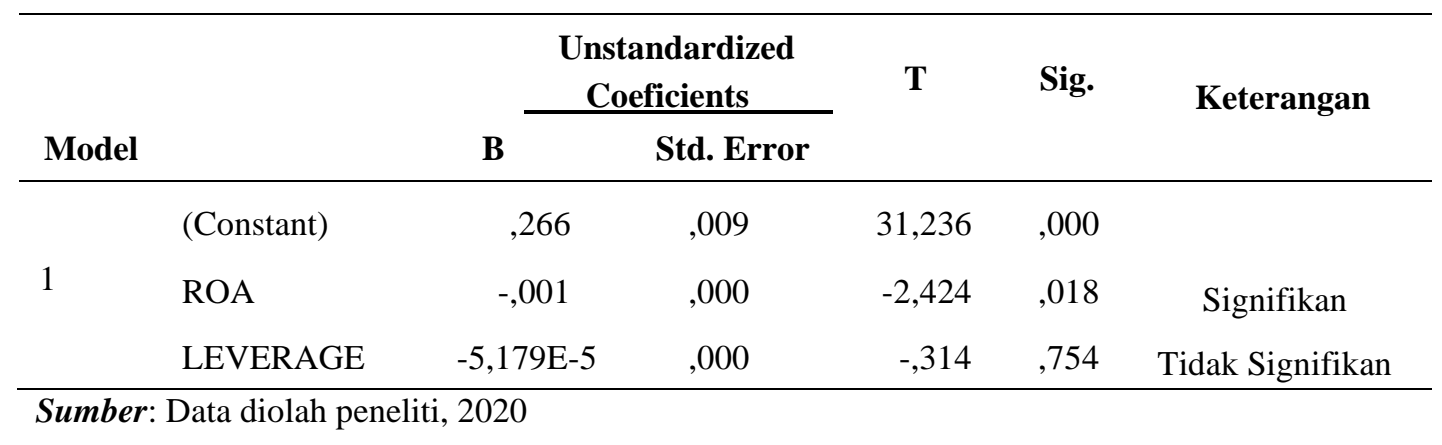

Variabel ROA (X1) menunjukan nilai probabilitas sebesar 0,018 yang berarti memiliki nilai lebih kecil dari taraf signifikansi 0,05 . Hal ini berarti ROA berpengaruh terhadap agresivitas pajak secara parsial. Selain itu ROA memperoleh nilai koefisien sebesar $-0,001$, hal tersebut menunjukan hubungan yang tidak searah antara ROA dengan agresivitas pajak. Artinya setiap tambahan ROA sebesar 1 satuan akan mengakibatkan penurunan agresivitas pajak sebesar 0,001. Sehingga dapat dikatakan bahwa profitabilitas berpengaruh negatif terhadap agresivitas pajak.

Variabel leverage (X2) mendapatkan nilai probabilitas sebesar 0,754 yang berarti memiliki nilai lebih besar dari taraf signifikansi 0,05 . Hal ini berarti leverage tidak berpengaruh terhadap agresivitas pajak secara parsial. Selain itu leverage memiliki nilai koefisien $-5,179$, hal tersebut menunjukan hubungan yang tidak searah antara leverage dengan agresivitas pajak. Artinya setiap tambahan leverage sebesar 1 satuan akan mengakibatkan penurunan agresivitas pajak sebesar 5,179. 
Uji simultan (uji F) digunakan untuk menunjukan apakah semua variabel bebas (independen) yang dimasukan dalam model mempunyai pengaruh secara bersama-sama (simutan) terhadap variabel terikat (dependen) (Ghozali, 2018).

Tabel 8.

Uji Hipotesis Simultan

\begin{tabular}{ccccc}
\hline Model & F & Sig. & Keterangan \\
\hline 1 & Regression & 3,335 &, $040^{\mathrm{b}}$ & Signifikan \\
\hline
\end{tabular}

Sumber: Data diolah peneliti, 2020

Berdasarkan hasil pengujian diperoleh nilai $\mathrm{F}$ hitung 3,335 > F tabel 3,11 dan nilai signifikansi $0,040<0,05$. Berdasarkan uji hipotesis tersebut maka $\mathrm{H}_{\mathrm{a}}$ diterima dan $\mathrm{H}_{0}$ ditolak, sehingga dapat disimpulkan bahwa profitabilitas dan leverage berpengaruh secara simultan terhadap agresivitas pajak pada perusahaan manufaktur subsektor konsumsi yang terdaftar di BEI.

Koefisien Determinasi digunakan untuk mengetahui kekuatan pengaruh Profitabilitas dan Leverage terhadap agresivitas pajak (Ghozali, 2018). Nilai $\mathrm{R}^{2}$ yang kecil berarti variabel-variabel dalam menjelaskan variabel dependen amat terbatas. Nilai yang mendekati satu berarti variabel-variabel dependen memberikan hampir semua informasi yang dibutuhkan untuk memprediksi variasi variabel dependen.

Tabel 9.

Hasil uji Determinasi

\begin{tabular}{cccc}
\hline Model & $\begin{array}{c}\text { R } \\
\text { Square }\end{array}$ & Adjusted R Square & $\begin{array}{c}\text { Std. Error of } \\
\text { the Estimate }\end{array}$ \\
\hline 1 &, 074 &, 052 & 0,021105 \\
\hline Sumber: Data diolah peneliti, 2020 & &
\end{tabular}


Nilai koefisien determinasi sebesar 0,074 atau 7,4\%. Hal ini menunjukan bahwa variabel yang diteliti yaitu profitabilitas dan leverage berpengaruh sangat kecil dan amat terbatas dalam menjelaskan variabel dependen. sedangkan sisanya sebesar 92,6\% dipengaruhi oleh faktor lain yang tidak diteliti dalam penelitian ini.

Pengaruh Profitabilitas terhadap Agresivitas Pajak. Tingkat profitabilitas memiliki pengaruh negatif dengan tarif pajak efektif karena semakin efisien perusahaan maka semakin sedikit pajak yang harus dibayar perusahaan. Dari perspektif perpajakan, semakin tinggi laba atas aset (ROA), semakin rendah beban pajak perusahaan, karena perusahaan berpenghasilan tinggi akan berhasil menggunakan insentif pajak dan keringanan pajak lainnya yang dapat mengakibatkan tarif pajak efektif perusahaan yang lebih rendah. Semakin rendah tarif pajak efektif mengindikasikan tingkat agresivitas pajak perusahaan semakin tinggi.

Disisi lain ketika laba yang diperoleh semakin besar maka otomatis pajak penghasilan akan meningkat sesuai dengan peningkatan laba perusahaan. Manajer yang bertindak sebagai agen akan berusaha untuk mengurangi pajak perusahaan semaksimal mungkin, agar tidak mengurangi kompensasi kinerja manajer akibat beban pajak yang menggerus laba perusahaan.

Perusahaan dengan profitabilitas tinggi memiliki peluang untuk memposisikan diri dalam perencanaan perpajakan, sehingga mengurangi beban pajak terutang. Perseroan dapat mengurangi beban perpajakannya dengan menyeleksi atau menghasilkan PNBP dengan menggunakan PPh Pasal 4 ayat 3 tentang objek tidak kena pajak. Misalnya perseroan terbatas (PT) dapat 
melakukan investasi pada suatu perusahaan atau badan usaha di Indonesia, dan dividen yang diterima PT akan diklasifikasikan sebagai penghasilan tidak kena pajak. Dengan ketentuan PT memiliki sekurang-kurangnya 25\% dari total modal disetor perusahaan sebagaimana diatur pada pasal 4 ayat 3 UU PPh (Pohan, 2016). Hasil penelitian ini mendukung penelitian yang dilakukan oleh (Maharani \& Suardana, 2014; Kurniasih \& Ratna Sari, 2013) yang menyatakan bahwa profitablitas berpengaruh negatif pada agresivitas pajak yang dilakukan perusahaan.

Berbeda dengan penelitian yang dilakukan oleh (Darmadi, 2013) dan (Nugraha \& Meiranto, 2015) yang menyatakan bahwa profitabilitas tidak berpengaruh terhadap agresivitas pajak perusahaan. Perusahaan yang menghasilkan pendapatan tinggi seringkali dianggap berhasil mengelola manajemen dan memenuhi harapan pemilik perusahaan. Maka dari itu perusahaan yang mampu menghasilkan keuntungan dalam jumlah besar juga harus siap menanggung pajak yang harus dibayarkan sesuai dengan kewajibannya. Semakin besar profitabilitas perusahaan, maka perusahaan akan mengurangi agresivitas pajaknya karena hal tersebut akan mempengaruhi laporan keuangan perusahaan.

Pengaruh Leverage terhadap Agresivitas pajak. Tingkat leverage tidak memiliki pengaruh terhadap agresivitas pajak perusahaan. Karena ada faktorfaktor tertentu yang membuat perusahaan tidak memanfaatkan beban bunga utangnya untuk mengurangi beban pajak, sehingga tingkat utang tidak berpengaruh terhadap agresivitas pajak. Padahal menurut pasal 6 ayat (1) a, perusahaan yang mempunyai utang akan mendapat insentif perpajakan berupa 
potongan bunga pinjaman (UU No. 36 Th 2008, 2008).

Disisi lain perusahaan yang memiliki tingkat hutang yang tinggi akan diawasi oleh pihak pemberi pinjaman, sehingga perusahaan cenderung lebih patuh akan kesadaran kewajiban perpajakannya sesuai dengan aturan hukum yang berlaku. Perusahaan juga berupaya semaksimal mungkin untuk memenuhi perjanjian utangnya, sehingga tidak terjadi pelanggaran kontrak. Denda atau pelanggaran akan menyebabkan perusahaan mendapatkan evaluasi kinerja yang buruk dari kreditur dan akan menurunkan kepercayaan pasar yang akan berdampak pada turunnya harga saham perusahaan.

Pertimbangan lain yang diambil oleh perusahaan apabila utang yang dimiliki terlalu besar, akan berdampak pada besarnya risiko yang dihadapi oleh perusahaan. Utang yang berlebihan juga akan menurunkan kepercayaan stakeholder terutama investor, karena perusahaan akan menghadapi resiko yang sangat besar dimasa yang akan datang. Hal ini dapat mengindikasikan bahwa perusahaan akan mengurangi agresivitas pajaknya karena terlilit utang yang besar. Hasil penelitian ini diperkuat oleh penelitian yang dilakukan (Yuliana \& Wahyudi, 2018) dan (Sugitha \& Supadmi, 2016) yang menunjukan hasil bahwa leverage tidak berpengaruh terhadap agresivitas pajak.

Berbeda dengan penelitian yang dilakukan oleh (Sukmawati \& Rebecca, 2016) dan (Lestari et al., 2016) yang menyatakan bahwa semakin tinggi nilai rasio leverage maka semakin tinggi jumlah pembiayaan utang pihak ketiga yang digunakan oleh perusahaan, dan semakin tinggi pula beban bunga yang dihasilkan oleh utang tersebut. Beban bunga timbul dari penggunaan utang termasuk dalam 
biaya yang dapat mengurangi penghasilan kena pajak (deductible expense). Pasal 6 ayat (1) a, mengatur bahwa dalam perhitungan pajak penghasilan ( $\mathrm{PPh}$ ) badan, bunga dapat dikurangkan sebagai biaya (deductible tax) sebagai bagian dari biaya usaha (UU No. 36 Th 2008, 2008).

\section{SIMPULAN DAN SARAN}

Profitabilitas berpengaruh negatif terhadap agresivitas pajak pada perusahaan manufaktur subsektor konsumsi yang terdaftar di Bursa Efek Indonesia periode 2015-2019. Leverage tidak berpengaruh terhadap agresivitas pajak pada perusahaan manufaktur subsektor konsumsi yang terdaftar di Bursa Efek Indonesia periode 2015-2019. Profitabilitas dan Leverage secara simultan berpengaruh terhadap agresivitas pajak pada perusahaan manufaktur subsektor konsumsi yang terdaftar di Bursa Efek Indonesia periode 2015-2019.

Saran bagi investor dalam melakukan pengambilan keputusan investasi harus melakukan penilaian sebelumnya tentang bagaimana kinerja suatu perusahaan dan juga kepatuhan perusahaan terhadap pajak. Bagi perusahaan yang mempunyai profitabilitas tinggi diharapkan dapat memenuhi kewajiban perpajakannya sesuai dengan ketentuan yang berlaku. Agresivitas pajak memang merupakan cara untuk mengurangi beban pajak secara legal, tetapi pasti akan berdampak buruk bagi perusahaan, investor, dan juga pemerintah. Saran bagi akademik baik peneliti maupun pembaca diharapkan bahwa penelitian ini dapat digunakan sebagai referensi untuk melanjutkan penelitian terkait dengan variabel profitabilitas, leverage, dan agresivitas pajak. Penelitian dapat dilakukan dengan menambahkan variabel independen lainnya seperti ukuran perusahaan, komite 
audit, komisaris independen, dan CSR. Selain itu, penelitian ini dapat dilakukan dengan menambahkan periode penelitian dan dengan melakukan penelitian pada perusahaan manufaktur subsektor lain dan sebagainya diluar perusahaan manufaktur untuk mendapatkan hasil yang lebih signifikan dan menggunakan metode dan alat uji yang lebih lengkap dan akurat. Sehingga dapat menghasilkan kesimpulan penelitian yang lebih baik dan juga valid.

\section{REFERENSI}

BPS. (2015). Statistik Indonesia 2015. In Statistik Indonesia.

Darmadi, I. N. H. (2013). Analisis Faktor Yang Mempengaruhi Pajak Dengan Indikator Tarif Pajak Efektif. In E-jurnal Akuntansi Universitas Diponegoro.1(1). 368-379.

Darmawan, I., \& Sukartha, I. (2014). Pengaruh Penerapan Corporate Governance, Leverage, Roa, Dan Ukuran Perusahaan Pada Penghindaran Pajak. E-Jurnal Akuntansi. 9(1). 143-161.

Ghozali, I. (2018). Aplikasi Analisis Multivariate dengan Program IBM SPSS. Yogyakarta: Universitas Diponegoro. (Edisi 9). Semarang: Badan Penerbit Universitas Diponegoro.

Hanafi, Mamduh M; Halim, A. (2012). Analisis Laporan Keuangan, Edisi Keempat. Yogyakarta: UPP STIM YKPN.

Kamila, P. A., \& Martani, D. (2014). Analisis Hubungan Agresivitas Pelaporan Pada Saat Terjadinya Penurunan Tarif Pajak. Simposium Nasional Akuntansi XVII Lombok.

Kasmir. (2014). Analisis Laporan Keuangan, Edisi Satu, Cetakan Ketujuh. In Raja Grafindo Persada.

Kementrian Keuangan. (2018). Apbn 2018. Kementerian Keuangan Republik Indonesia.

Kurniasih, T., \& Ratna Sari, M. (2013). PENGARUH RETURN ON ASSETS, LEVERAGE, CORPORATE GOVERNANCE, UKURAN PERUSAHAAN DAN KOMPENSASI RUGI FISKAL PADA TAX AVOIDANCE. Buletin 
Studi Ekonomi.18(1). 1-9.

Lestari, M. K., Rifa, D., \& Rahmawati, N. (2016). PENGARUH SIZE, LEVERAGE, PROFITABILITY, DAN CAPITAL INTENSITY RATIO TERHADAP EFFECTIVE TAX RATE (Studi Empiris Pada Perusahaan Manufaktur yang Listing di BEI Tahun 2012-2014). Jurnal Fakultas Ekonomi.5(2). 1-10

Lokadata. (2019). Target dan realisasi pajak, 2007-2019. Lokadata.Id.

Luke, L., \& Zulaikha, Z. (2016). ANALISIS FAKTOR YANG MEMPENGARUHI AGRESIVITAS PAJAK. Jurnal Akuntansi Dan Auditing. 13(1).80-96.

Maharani, I. G. A. C., \& Suardana, K. A. (2014). Pengaruh Corporate Governance , Profitabilitas Dan Karakteristik Eksekutif Pada Tax Avoidance Perusahaan Manufaktur. E-Jurnal Akuntansi Universitas Udayana. 9(2). 525-539.

Pohan, C. A. (2016). Manajemen Perpajakan Strategi Perencanaan Pajak dan Bisnis. Akarta: PT Gramedia.

suara.com. (2017). Fitra: Setiap Tahun, Penghindaran Pajak Capai Rp110 Triliun. 30 November.

Sugitha, I., \& Supadmi, N. (2016). Pengaruh Karakteristik Perusahaan Dan Beban Iklan Pada Tindakan Penghindaran Pajak. E-Jurnal Akuntansi.17(2). 13111341.

Sugiyono. (2012). Metode Penelitian Kuantitatif, Kualitatif dan R \& D.Bandung:Alfabeta. Metode Penelitian Kuantitatif, Kualitatif Dan $R$ \& D.Bandung:Alfabeta. https://doi.org/10.1017/CBO9781107415324.004

Sukmawati, F., \& Rebecca, C. (2016). Pengaruh Likuiditas dan Leverage terhadap Agresivitas Pajak Perusahaan. Conference on Management and Behavioral Studies.1(9).1-12.

Susanto, L., Yanti, Y., \& Viriany, V. (2018). Faktor-faktor yang mempengaruhi agresivitas pajak. Jurnal Ekonomi. 23(1). 330-340. https://doi.org/10.24912/je.v23i1.330

Suyanto, K. D., \& Supramono. (2012). Likuiditas, Leverage, Komisaris Independen, Dan Manajemen Laba Terhadap Agresivitas Pajak Perusahaan. Likuiditas, Leverage, Komisaris Independen, Dan Manajemen Laba Terhadap Agresivitas Pajak Perusahaan.

Undang-Undang No.16 Tahun 2009 Tentang Ketentuan Umum dan Tata Cara 
Perpajakan. (2009). Undang-Undang No.16 Tahun 2009 Tentang Ketentuan Umum dan Tata Cara Perpajakan. Nature.

UU No. 36 Th 2008. (2008). Undang Undang No 36 Tahun 2008 tentang Pajak Penghasilan. In Jakarta: Sekertariat Negara.

Yeye, S., Widyawati Ratih, \& Nuraini. (2018). Pengaruh Ukuran Perusahaan, Leverage, Profitabilitas, Capital Intensity Ratio, Dan Komisaris Independen Terhadap Effective Tax Rate (Studi Empiris Pada Perusahaan Manufaktur Yang Terdaftar Di Bursa Efek Indonesia Pada Tahun 2014-2016). Isbn: 978979-3649-99-3.

Yuliana, I. F., \& Wahyudi, D. (2018). Pengaruh likuiditas, profitabilitas, leverage, ukuran perusahaan, capital intensity dan inventory intensity terhadap agresivitas pajak (Studi Empiris pada Perusahaan Manufaktur yang Terdaftar di Bursa Efek Indonesia Tahun 2013 - 2017). Journal of Chemical Information and Modeling. 7(2).25-35. 